\title{
Scutia buxifolia Reissek essential oil: in vitro antioxidant and antimicrobial activities
}

\author{
ALINE A. BOLIGON ${ }^{1}$, MARIANA PIANA ${ }^{1}$, THIELE F. DE BRUM ${ }^{1}$, \\ AMANDA L.F. FROEDER ${ }^{1}$, BIANCA V. BELKE ${ }^{1}$, THIAGO G. SCHWANZ ${ }^{2}$, \\ DÉBORA N. MARIO ${ }^{3}$, SYDNEY H. ALVES ${ }^{3}$ and MARGARETH L. ATHAYDE ${ }^{1}$ \\ ${ }^{1}$ Centro de Ciências da Saúde, Departamento de Farmácia Industrial, Universidade Federal de Santa Maria, \\ Prédio 26, Sala 1115, 97105-900 Santa Maria, RS, Brasil \\ ${ }^{2}$ Núcleo de Análises e Pesquisas Orgânicas/NAPO, Departamento de Química, \\ Universidade Federal de Santa Maria, Prédio 15, 97105-900 Santa Maria, RS, Brasil \\ ${ }^{3}$ Laboratório de Pesquisa Micológica, Departamento de Microbiologia e Parasitologia, \\ Universidade Federal de Santa Maria, Prédio 20, 97105-900 Santa Maria, RS, Brasil
}

Manuscript received on December 19, 2012; accepted for publication on December 10, 2013

\begin{abstract}
The volatile oil from the stem bark of Scutia buxifolia (Rhamnaceae) has been obtained by hydrodistillation and analyzed by GC-MS. Twenty-one components were identified representing $99.93 \%$ of the total oil composition, spathulenol (35.87\%), $\beta$-cubebene (17.26\%), germacrene D (6.43\%), linalool $(5.19 \%)$, carvacrol $(4.05 \%)$ were the main components of S. buxifolia essential oil. Antioxidant and antimicrobial properties of the essential oil were evaluated by free radical scavenging (DPPH) assay and micro broth dilution method, respectively. S. buxifolia essential oil presented interesting radical scavenging activity $\left(\mathrm{IC}_{50}=15.03 \pm 0.11 \mu \mathrm{g} / \mathrm{mL}\right)$. The antibacterial assay showed that $S$. buxifolia stem bark essential oil was moderately active against the Staphylococcus aureus and Micrococcus sp. (MIC $=500 \mu \mathrm{g} / \mathrm{mL}$ ) and Escherichia coli $(250 \mu \mathrm{g} / \mathrm{mL})$. To the best of our knowledge, this is the first study on the composition, antioxidant and antimicrobial activities of essential oil from the $S$. buxifolia collected from Brazil.
\end{abstract}

Key words: Scutia buxifolia, essential oil, antioxidant, antimicrobial.

\section{INTRODUCTION}

Scutia buxifolia Reissek belongs to the Rhamnaceae family and is commonly known in Brazil as coronilha, being a native tree from of Southern Brazil, Uruguay and Northern Argentina (Wasicky et al. 1964). In these regions, an aqueous infusion prepared with stem bark and leaves of Scutia buxifolia has been described and widely used in folk medicine for cardiotonic, diuretic and antihypertensive purposes (Boligon et al. 2009,

Correspondence to: Aline Augusti Boligon

E-mail: alineboligon@hotmail.com
Da Silva et al. 2012). Phytochemical screening of fractions of Scutia buxifolia bark revealed the presence of cyclopeptide alkaloids (Maldaner et al. 2011), polyphenols and flavonoids in fractions of Scutia buxifolia leaves and stem bark (Boligon et al. 2009, 2012a, b). Antimicrobial activities of some cyclopeptide alkaloids isolated from the root bark of this species were reported by Morel et al. (2005) using the bioautography method. Cytotoxicity of extracts from leaves, twigs and stem bark of the plant were evaluated by the Artemia salina assay, as well as the antimicrobial activity against 
a panel of microorganism strains (Boligon et al. $2012 b$ ). Extracts of the leaves and stem bark of $S$. buxifolia were effective against lipid peroxidation by inhibiting the production of thiobarbituric acid reactive substances and also presented DPPH scavenger activity (Boligon et al. 2009).

Considering that the infusion and decoction of this plant are used in folk medicine, we were interested in detecting the volatile constituents that get into water. This paper represents the first report on the oil composition, antioxidant and antimicrobial activity of the essential oils of $S$. buxifolia stem bark.

\section{MATERIALS AND METHODS}

\section{Plant MATERIAL}

Scutia buxifolia (Rhamnaceae) stem bark was collected in Dom Pedrito, state of Rio Grande do Sul, Brazil, on June of 2011 (coordinates $30^{\circ} 59^{\prime} 09^{\prime}$ 'S and $\left.54^{\circ} 27^{\prime} 44^{\prime \prime} \mathrm{W}\right)$. They were identified and archived as voucher specimens in the herbarium of the Department of Biology at the Federal University of Santa Maria by register number SMBD 10919.

\section{EXTRACTION OF THE ESSENTIAL OIL}

The fresh material $(250 \mathrm{~g})$ of the plant stem bark was extracted using a hydrodistillation process in a Clevenger apparatus for 4 hours. Oil was dried over anhydrous sodium sulphate and, after filtration, stored at $-4{ }^{\circ} \mathrm{C}$ until test and analysis. The yield in terms of percentage of the fresh weight of the stem bark was determined.

\section{GAS CHROMATOGRAPHY (GC-FID)}

The gas chromatography (GC) analyses were carried out using an Agilent Technology 6890N GC-FID system, equipped with DB-5 capillary column (30m x $0.25 \mathrm{~mm}$; film thickness $0.25 \mathrm{~mm}$ ) and connected to an FID detector. The injector and detector temperatures were set to $280^{\circ} \mathrm{C}$. The carrier gas was helium, at a flow rate of $1.3 \mathrm{~mL} / \mathrm{min}$. The thermal programmer was $50-300^{\circ} \mathrm{C}$ at a rate of $5^{\circ} \mathrm{C} / \mathrm{min}$. Two replicates of samples were processed in the same way. Component relative concentrations were calculated based on GC peak areas without using correction factors. The injection volume of the oil was $1 \mu \mathrm{L}$ (Verma et al. 2010, Nazemiyeh et al. 2011).

\section{GAS CHROMATOGRAPHY-MASS SPECTROMETRY (GC-MS)}

GC-MS analyses were performed on an Agilent Technology AutoSystem XL GC-MS system operating in the EI mode at $70 \mathrm{eV}$, equipped with a split/splitless injector $\left(250^{\circ} \mathrm{C}\right)$. The transfer line temperature was $280^{\circ} \mathrm{C}$. Helium was used as carrier gas $(1.3 \mathrm{~mL} / \mathrm{min})$ and the capillary columns used were a HP 5MS ( $30 \mathrm{~m}$ x $0.25 \mathrm{~mm}$; film thickness 0.25 $\mathrm{mm}$ ) and an HP Innowax (30m x 0.32mm i.d., film thickness $0.50 \mathrm{~mm}$ ). The temperature programmer was the same as that used for the GC analyses. The injected volume was $1 \mu \mathrm{L}$ of the essential oil.

IDENTIFICATION OF THE COMPONENTS

Identification of the constituents was performed on the basis of retention index (RI), determined with reference of the homologous series of n-alkanes, $\mathrm{C}_{7}-\mathrm{C}_{30}$, under identical experimental conditions, comparing with the mass spectra library search (NIST and Wiley), and with the mass spectra literature date Adams (1995). The relative amounts of individual components were calculated based on the $\mathrm{CG}$ peak area (FID response).

\section{QUALITATIVE ANALYSIS OF ANTIOXIDANT ACTIVITY}

Ten microlitres of 1:50 dilution of the essential oil in hexane were applied to TLC plates (silica gel 60 $\mathrm{GF}_{254}$ ), quercetin and ascorbic acid (Sigma-Aldrich, $\geq 98 \%$ HPLC) standards were also used. The TLC plate was sprayed with a $0.2 \%$ 1,1-diphenyl-2picrylhydrazyl (DPPH) solution in methanol and left at room temperature for 30 minutes. Active compounds appeared as yellow spots against a purple background, indicating possible antioxidant activity (Mensor et al. 2001). 


\section{QUANTITATIVE ANALYSIS OF ANTIOXIDANT ACTIVITY}

The antioxidant activity of the essential oil was evaluated by monitoring its ability in quenching the stable free radical DPPH, according to a slightly modified method previously described by Mensor et al. (2001). Spectrophotometric analysis was used to measure the free radical-scavenging capacity and to determine the scavenging concentration or inhibitory concentration $\left(\mathrm{IC}_{50}\right)$. The $\mathrm{DPPH}$ quenching ability was expressed as $\mathrm{IC}_{50}$ (the essential oil concentration $(\mu \mathrm{g} / \mathrm{mL})$ required to inhibit $50 \%$ of the DPPH in the assay medium). Six different ethanol dilutions of essential oil at $250,125,62.5,31.25,15.62$ and $7.81 \mu \mathrm{g} / \mathrm{mL}$ were mixed with $1.0 \mathrm{~mL}$ of DPPH $0.3 \mathrm{mM}$ in ethanol solution. After $30 \mathrm{~min}$, absorption was measured at $518 \mathrm{~nm}$, where the radical DPPH showed maximum absorption. A solution of DPPH $(1 \mathrm{~mL} ; 0.3 \mathrm{mM})$ in ethanol $(2.5 \mathrm{~mL})$ was used as a negative control and ascorbic acid in the same concentrations used for the essential oil provided the positive control. Ethanol was used to calibrate the spectrophotometer. The test was performed in triplicate and the calculation of the antioxidant activity followed the equation: $\%$ Inhibition $=\left[\left(\mathrm{A}_{0}-\mathrm{A}_{1}\right) / \mathrm{A}_{0}\right] \times 100$, where $\mathrm{A}_{0}$ was the absorbance of the control sample (without essential oil) and $\mathrm{A}_{1}$ was the absorbance in the presence of the sample (Boligon et al. 2009).

\section{ANTIMICROBIAL ASSAY DETERMINATION}

The essential oil was evaluated against Candida albicans ATCC 28967, Cryptococcus neoformans ATCC 2857, Klebsiella pneumoniernaae ATCC 700603, Pseudomonas aeruginosa ATCC 27853, Enterococcus faecalis ATCC 51299, Proteus mirabilis ATCC 7002, Staphylococcus aureus ATCC 29213, Micrococcus sp. ATCC 7468, Malassezia sp., Aspergillus sp., Aeromonas sp., S. aureus and Escherichia coli (clinical isolates). The minimal inhibitory concentration (MIC) of the oil against the test microorganisms were determined by the broth microdilution method M27-A2 (2002). The experiments were repeated twice and the results were determined as an average value. Six different dilutions (1000, 750, 500, 250, 125, and $62.5 \mu \mathrm{g} /$ $\mathrm{mL}$ ) were prepared. The first dilution was made in DMSO and further dilutions in the culture medium. Bacterial strains were cultured overnight at $37^{\circ} \mathrm{C}$ in Mueller-Hinton broth. Yeasts were cultured overnight at $30{ }^{\circ} \mathrm{C}$ in Potato dextrose broth. The first column of the plate was reserved for negative control wells (without inoculants) and the last column, for the positive growth control wells (without antimicrobial agents). The MIC was considered as the lowest concentration of the essential oil inhibiting the total growth of microorganisms. MIC was detected by lack of visual turbidity (matching the negative growth control).

STATISTICAL ANALYSIS

The obtained antioxidant and antimicrobial results were stated in mean \pm standard deviation of three replicates.

\section{RESULTS AND DISCUSSION}

The pale yellowish essential oil of the fresh stem bark of S. buxifolia was obtained by hydrodistillation in the yield of $0.57 \%$. Essential oil was analyzed by GC-FID and GC-MS systems and the oil components were identified both quantitatively and qualitatively. Twenty-one components, representing $99.93 \%$ of the total composition, were identified, of which $82.81 \%$ were sesquiterpenes and $17.12 \%$ were monoterpenes (Table I).

The main components in the oil were spathulenol (35.87\%), $\quad \beta$-cubebene (17.26\%), germacrene D (6.43\%), linalool (5.19\%), carvacrol (4.05\%), $\alpha$-copaene (3.56\%), cubenol (2.80\%), $\gamma$-Eudesmol (2.75\%), 1,8-Cineol (2.73\%), Thymol acetate (2.54\%), Butylated hydroxytoluene (2.49\%), cedrene, $\alpha$-eudesmol, globulol, cyclosativene, thymol, among others, as minor constituents. Spathulenol, the most abundant component of this oil, has also been reported in the oil of other species 
TABLE I

Chemical compounds present in Scutia buxifolia stem bark essential oil.

\begin{tabular}{cccccc}
\hline $\mathrm{Rt}(\mathrm{min})$ & Compounds & \multicolumn{1}{c}{$(\%)$} & $\mathrm{RI}^{\mathrm{a}}$ & $\mathrm{RI}^{\mathrm{b}}$ & Mol. Formula \\
\hline & & \multicolumn{2}{c}{ Monoterpenes } & & \\
3.273 & $\alpha$-Pinene & 0.97 & 935 & 939 & $\mathrm{C}_{10} \mathrm{H}_{16}$ \\
3.692 & $\beta$-Pinene & 1.06 & 981 & 982 & $\mathrm{C}_{10} \mathrm{H}_{16}$ \\
11.450 & 1,8 -Cineol & 2.73 & 1029 & 1029 & $\mathrm{C}_{10} \mathrm{H}_{18} \mathrm{O}$ \\
12.045 & Linalool & 5.19 & 1078 & 1081 & $\mathrm{C}_{10} \mathrm{H}_{18} \mathrm{O}$ \\
12.629 & Pulegol & 0.85 & 1213 & 1209 & $\mathrm{C}_{10} \mathrm{H}_{18} \mathrm{O}$ \\
16.250 & Thymol & 1.36 & 1288 & 1290 & $\mathrm{C}_{10} \mathrm{H}_{14} \mathrm{O}$ \\
16.948 & Carvacrol & 4.05 & 1296 & 1298 & $\mathrm{C}_{10} \mathrm{H}_{14} \mathrm{O}$ \\
18.041 & Eugenol & 0.91 & 1354 & 1356 & $\mathrm{C}_{10} \mathrm{H}_{12} \mathrm{O}_{2}$ \\
& & Sesquiterpenes & & \\
19.531 & Thymol acetate & 2.54 & 1357 & 1355 & $\mathrm{C}_{12} \mathrm{H}_{16} \mathrm{O}_{2}$ \\
20.920 & Cyclosativene & 1.87 & 1365 & 1368 & $\mathrm{C}_{15} \mathrm{H}_{24}$ \\
23.760 & $\alpha$-Copaene & 3.56 & 1378 & 1376 & $\mathrm{C}_{15} \mathrm{H}_{24}$ \\
25.934 & $\beta$-Cubebene & 17.26 & 1400 & 1390 & $\mathrm{C}_{15} \mathrm{H}_{24}$ \\
28.486 & $\beta$-Elemene & 0.47 & 1390 & 1391 & $\mathrm{C}_{15} \mathrm{H}_{24}$ \\
28.491 & Cedrene & 2.03 & 1405 & 1409 & $\mathrm{C}_{15} \mathrm{H}_{24}$ \\
29.012 & $\alpha$-Humulene & 1.21 & 1454 & 1454 & $\mathrm{C}_{15} \mathrm{H}_{24}$ \\
30.245 & Germacrene D & 6.43 & 1477 & 1480 & $\mathrm{C}_{15} \mathrm{H}_{24}$ \\
31.871 & Butylated hydroxytoluene & 2.49 & 1519 & 1512 & $\mathrm{C}_{15} \mathrm{H}_{24} \mathrm{O}$ \\
33.502 & Spathulenol & 35.87 & 1576 & 1576 & $\mathrm{C}_{15} \mathrm{H}_{24} \mathrm{O}$ \\
35.127 & Globulol & 1.59 & 1583 & 1583 & $\mathrm{C}_{15} \mathrm{H}_{26} \mathrm{O}$ \\
37.458 & $\gamma$-Eudesmol & 2.75 & 1633 & 1630 & $\mathrm{C}_{15} \mathrm{H}_{26} \mathrm{O}$ \\
40.125 & Cubenol & 2.80 & 1643 & 1642 & $\mathrm{C}_{15} \mathrm{H}_{26} \mathrm{O}$ \\
42.113 & $\alpha$-Eudesmol & 1.94 & 1656 & 1652 & $\mathrm{C}_{15} \mathrm{H}_{26} \mathrm{O}$ \\
& & & & & \\
\hline & Total identified (\%) & 99.93 & & & \\
\hline
\end{tabular}

Relative proportions of the essential oil constituents were expressed as percentages. Rt $=$ Retention time according to order on MS. ${ }^{a}$ Retention indices experimental (based on homologous series of $n$-alkane $\mathrm{C}_{7}-\mathrm{C}_{30}$ ).

${ }^{\mathrm{b}}$ Retention indices from literature (Adams 1995).

such as Baccharis uncinella (16.41\%), Stevia rebaudiana (15.41\%), Origanum vulgare (11.67\%) and Baccharis dracunculifolia (9.54\%) (Al-Ja' fari et al. 2011, Muanda et al. 2011, Xavier et al. 2011). The second major component of the oil, $\beta$-cubebene, has also been found in the oils of Dendropanax morbifera (Chung et al. 2010) and Cinnamomum osmophloeum (Lin et al. 2007 ) in about $4.19 \%$ and $59.4 \%$, respectively. Germacrene D, the third major compound present, has also been found in the oils of Artemisia annua (15.64\%), Baccharis uncinella (14.87\%), Campomanesia adamantium (11.82\%), Tagetes minuta $(10.00 \%)$ and Origanum vulgare $(8.11 \%)$ (Ghiasvand et al. 2011).

Many in vitro studies have addressed the antioxidant and radical-scavenging properties of essential oils (Edris, 2007, Gourine et al. 2010, Fabri et al. 2012). In particular, DPPH radical is widely used for quickly assessing the ability of antioxidants to transfer labile $\mathrm{H}$ atoms to radicals (Brand-Williams et al. 1995). Following a similar line of thought, the essential oil was subjected to a preliminary test in order to verify the antioxidant activity using the DPPH free radical scavenging assay. Therefore, the antiscavenging ability of the essential oil applied on silica 
gel TLC plate was performed. One sample yellow spot could be observed immediately after spraying DPPH reagent on the TLC plate, suggesting some antioxidant activity for this oil, with intensity and color similar to quercetin and ascorbic acid used as standards. However, in order to get relevant data, a single method for testing antioxidant activities of essential oils is not recommended due to their complex composition. So, this test was the first step in the screening of the potential activity of this essential oil.

In the DPPH assay quantitative, antioxidants are typically characterized by their $\mathrm{IC}_{50}$ value, concentration necessary to reduce $50 \%$ of DPPH radical. The efficiency of the essential oil of $S$. buxifolia and ascorbic acid standard were evaluated for this method, and presented $\mathrm{IC}_{50}$ values of $15.03 \pm 0.11$ and $15.98 \pm 1.30 \mu \mathrm{g} / \mathrm{mL}$, respectively; compared to Thymbra capitatus $\left(\mathrm{IC}_{50}=19.27 \mu \mathrm{g} /\right.$ $\mathrm{mL})$, Pistacia atlantica $\left(\mathrm{IC}_{50}=18.95 \mu \mathrm{g} / \mathrm{mL}\right)$, Stevia rebaudiana $\left(\mathrm{IC}_{50}=19.26 \mu \mathrm{g} / \mathrm{mL}\right)$, Acacia Senegal $\left(\mathrm{IC}_{50}=17.89 \mu \mathrm{g} / \mathrm{mL}\right)$, Mycobacterium peregrinum $\left(\mathrm{IC}_{50}=13.48 \mu \mathrm{g} / \mathrm{mL}\right)$ and Mitracarpus frigidus $\left(\mathrm{IC}_{50}=38.00 \mu \mathrm{g} / \mathrm{mL}\right.$ ) (Bounatirou et al. 2007, Gourine et al. 2010, Muanda et al. 2011, Fabri et al. 2012), these results proved that the essential oils from $S$. buxifolia stem bark possess significant antioxidant properties. The antioxidant activity of essential oils has often been attributed to the presence of phenolic constituents, especially spathulenol, carvacrol and thymol (Bounatirou et al. 2007, Hazzit et al. 2009, Muanda et al. 2011, Viuda-Martos et al. 2011). This association was confirmed in our study, but other compounds also seem to play an important role such as eugenol $\left(\mathrm{IC}_{50}=1.26 \mu \mathrm{g} / \mathrm{mL}\right.$ by DPPH method $), \beta$-cubebene $\left(\mathrm{IC}_{50}=19.3 \mu \mathrm{g} / \mathrm{mL}\right)$ and butylated hydroxytoluene (BHT) (Yanishlieva et al. 1999, Gülçin et al. 2004, Jirovetz et al. 2006, Lin et al. 2007); these compounds are also present in the essential oil of S. buxifolia, and may account, in part, for the good antioxidant potential reported here. The results presented here may contribute to the knowledge of the antioxidant potential of the essential oils and provide some information for its uses.

The essential oil of $S$. buxifolia stem bark was also tested against 12 microorganisms; the antimicrobial screening is summarized in Table II. The essential oil showed only moderate activity against S. aureus and Micrococcus sp. (MIC $=500 \mu \mathrm{g} / \mathrm{mL}$ ) and E. coli $(250 \mu \mathrm{g} / \mathrm{mL})$, previous study describes the activity of $S$. buxifolia against $S$. aureus (Boligon et al. 2009). Sesquiterpenoids spathulenol, $\beta$-cubebene, germacrene D and carvacrol were the main components identified in this essential oil and may be responsible, in part, for the antimicrobial activity described, since spathulenol (Chinou et al. 2004) and carvacrol (Burt 2004) have been reported to present notable antimicrobial activity against bacterial infections. Spathulenol also showed a decrease in the proliferation of lymphocytes demonstrating immunomodulatory effects (Ziaei et al. 2011).

The antimicrobial activity of thymol $(1.36 \%$ in the essential oil of S. buxifolia) has been confirmed on bacteria such as E. coli (Rivas et al. 2010). Thymol has been shown to cause disruption of the cellular membrane, inhibition of ATPase activity, and release of intracellular ATP and other constituents (Raybaudi-Massilia et al. 2006, Viuda-Martos et al. 2011). The spathulenol, major compound described in the essential oil of S. buxifolia stem bark (35.87\%), evidenced a high activity against fungi strains dermatophytes such as Trichophyton mentagrophytes and Microsporum gypseum with MIC values ranging from 32 to $64 \mu \mathrm{g} / \mathrm{ml}$. Furthermore, the MIC value against Candida lactis-condensi and Penicillium purpurogenum for the spathulenol was $32 \mu \mathrm{g} / \mathrm{ml}$ (Al-Ja'fari et al. 2011). However, in our work that was not observed, since the essential oil of the $S$. buxifolia showed no activity against strains of fungi.

In conclusion, the analysis of the chemical composition of the essential oil of this plant and the preliminary evaluation of its antioxidant and antimicrobial activity is the first work described in 
the literature for this species, indicate that the data obtained here inspire more studies supporting the possibility of linking the chemical contents with particular biological properties.

TABLE II

Minimal inhibitory concentrations (MIC) of essential oil of the $S$. buxifolia stem bark.

\begin{tabular}{cc}
\hline Microorganisms & $\begin{array}{c}\text { Essential oil } \\
(\mu \mathrm{g} / \mathrm{mL})\end{array}$ \\
\hline Candida albicans & $>1000.00$ \\
Cryptococcus neoformans & $>1000.00$ \\
Klebisiella pneumoniernaae & $>1000.00$ \\
Pseudomonas aeruginosa & $>1000.00$ \\
Enterococcus faecalis & $>1000.00$ \\
Proteus mirabilis & $>1000.00$ \\
Malassezia sp. & $>1000.00$ \\
Aspergillus sp. & $>1000.00$ \\
Aeromonas sp. & $>1000.00$ \\
Staphylococcus aureus & 500.00 \\
Micrococcus sp. & 500.00 \\
Escherichia coli & 250.00 \\
\hline
\end{tabular}

\section{ACKNOWLEDGMENTS}

The authors would like to thank the professors from NAPO (Center for Analysis and Organic Research at the Federal Universtity of Santa Maria) for providing the CG/MS chromatograms and spectra and A.F. Morel (Department of Chemistry at Federal University of Santa Maria) for the assessment of the $n$-alkane series. The authors thank the financial support of Coordenação de Aperfeiçoamento de Pessoal de Nível Superior (CAPES) and Conselho Nacional de Desenvolvimento Científico e Tecnológico (CNPq).

\section{RESUMO}

O óleo volátil das cascas do caule de Scutia buxifolia (Rhamnaceae) foi obtido por hidrodestilação e analisados por CG-EM. 21 componentes foram identificados representando $99,93 \%$ da composição total de óleo, espatulenol (35,87\%), $\beta$-cubebene $(17,26 \%)$, germacreno D $(6,43 \%)$, linalol $(5,19 \%)$ e carvacrol $(4,05 \%)$ foram os principais componentes do óleo essencial de S. buxifolia. Propriedades antioxidantes e antimicrobianas do óleo essencial foram avaliadas através do ensaio do DPPH e do método de micro diluição em caldo, respectivamente. O óleo essencial de $S$. buxifolia apresentou interessante atividade de radical de limpeza $\left(\mathrm{IC}_{50}=15,03 \pm 0,11 \mu \mathrm{g} / \mathrm{mL}\right)$. O ensaio antibacteriano mostrou que $S$. buxifolia possui moderadamente atividade frente a $S$. aureus e Micrococcus sp. $(\mathrm{CIM}=500 \mu \mathrm{g} / \mathrm{mL})$ e E. coli $(250 \mu \mathrm{g} / \mathrm{mL})$. Tanto quanto pudemos avaliar, este é o primeiro estudo sobre a composicão química, atividade antioxidante e antimicrobiana do óleo essencial da cascas do tronco de $S$. buxifolia coletadas do Brasil.

Palavras-chave: Scutia buxifolia, óleo essencial, antioxidante, antimicrobiana.

\section{REFERENCES}

ADAMS RP. 1995. Identification of Essential Oil Components by Gas Chromato- graphy/Mass Spectroscopy. Allured Publishing Co. Carol Stream, Illinois, p. 456.

Al-JA'FARI AH, VILA R, FREIXA B, TOMi F, CASANOVA J, COSTA J AND CAÑIGUERAL S. 2011. Composition and antifungal activity of the essential oil from the rhizome and roots of Ferula hermonis. Phytochem 72: 1406-1413.

Boligon AA, Agertt V, JANOVIK V, CRUz RC, CAmpos MMA, Guillaume D, ATHAYde ML and Dos SANTOS ARS. 2012a. Antimycobacterial activity of the fractions and compounds from Scutia buxifolia. Braz J Pharmacog 22: $45-52$.

BOLIGON AA, JANOVIK V, FroHLICH JK, SPADER TB, FroEdER ALF, ALVES SH AND ATHAYDE ML. 2012b. Antimicrobial and cytotoxic activities of leaves, twigs and stem bark of Scutia buxifolia Reissek. Nat Prod Res 26: 939-944.

Boligon AA, Pereira RP, Feltrin AC, Machado MM, JANOVIK V, ROCHA JBT AND ATHAYDE ML. 2009. Antioxidant activities of flavonol derivatives from the leaves and stem bark of Scutia buxifolia Reiss. Bioresour Technol 100: 6592-6598.

Bounatirou S, Smiti S, Miguel MG, Faleiro L, Rejeb MN, NefFati M, Costa MM, Figueiredo AC, Barroso JG AND PEDRO LG. 2007. Chemical composition, antioxidant and antibacterial activities of the essential oils isolated from Tunisian Thymus capitatus Hoff. et Link. Food Chem 105: 146-155.

Brand-Williams W, Cuvelier ME and Berset C. 1995. Use of free radical method to evaluate antioxidant activity. Lebensm Wiss Technol 28: 25-30.

BURT S. 2004. Essential oils, their antibacterial properties and potential applications in foods - A Review. J Food Microbiol 3: 223-253.

Chinou JB, Bougatsos C And Perdetzouglou D. 2004. Chemical composition and antimicrobial activities of Helichrysum amorginum cultivated in Greece J Essential Oil Res 16: 243-247. 
Chung III M, SeO SH, Kang EY, PARK SD, PARK WH AND Moon HI. 2010. Chemical composition and larvicidal effects of essential oil of Dendropanax morbifera against Aedes aegypti L. Biochem Syst Ecol 37: 470-473.

Da Silva RCVAF, CRestania S, Souza P, Boligon AA, ATHAYDE ML, SANTOS ARS, MARQUES MCA, KASSUYAD CAL AND DA SILVA-SANTOS JE. 2012. Endotheliumdependent and independent vasorelaxation induced by an n-butanolic fraction of bark of Scutia buxifolia Reiss (Rhamanaceae). J Ethnopharmacol 141: 997-1004.

EDRIS AE. 2007. Pharmaceutical and therapeutic potentials of essential oils and their individual volatile constituents: A review. Phytotherapy Res 21: 308-323.

Fabri RL, Coimbra ES, Almeida AC, Siqueira EP, Alves TMA, ZANI CL AND SCIO E. 2012. Essential oil of Mitracarpus frigidus as a potent source of bioactive compounds. An Acad Bras Cienc 84: 1073-1080.

GHIASVAND AR, NASSERI M, FARSIZAEH S, MEShKatAlsadaT MH, SAdeghi-SARabi R, Shadabi S AND Borzoei M. 2011. Chemical Characterization of Cultivated Tagetes minuta L. by use of ultrasound-assisted head space SPME and GC-MS. Chromatographia 73: 1031-1035.

Gourine N, Yousfi M, Bombarda I, NAdjemi B, Stocker P AND GAYDOU EM. 2010. Antioxidant activities and chemical composition of essential oil of Pistacia atlantica from Algeria. Industrial Crops and Products 31: 203-208.

GÜLÇIN I, ŞAT IG, BEYDEMIR Ş, ELMASTAŞ M AND KÜFREVIOĞLU ÖI. 2004. Comparison of antioxidant activity of clove (Eugenia Caryophylata Thumb.) buds and lavander (Lavandula stoechas L.). Food Chem 87: 393-400.

Hazzit M, BaAliouamer A, Veríssimo AR, FAleiro ML AND Miguel MG. 2009. Chemical composition and biological activities of Algerian Thymus oils. Food Chem 116: 714-721.

Jirovetz L, Buchbauer G, Stollova I, Stoyanova A, Krastanov A AND SCHMidT E. 2006. Chemical composition and antioxidant properties of clove feaf essential oil. J Agric Food Chem 54: 6303-6307.

LIN KH, YEH SY, LIN MY, SHIH MC, YANG KT AND HWANG SY. 2007. Major chemotypes and antioxidative activity of the leaf essential oils of Cinnamomum osmophloeum Kaneh. from a clonal orchard. Food Chem 105: 133-139.

Maldaner G, Marangon P, IlHa V, CARo MSB, Burrow RA, DAlcol II AND Morel AF. 2011. Cyclopeptide alkaloids from Scutia buxifolia Reiss. Phytochemistry 72: 804-809.

Mensor LL, Menezes FS, LeItão GG, ReIS AS, Dos SAntos TC, COUBE CS AND LeITÃo SG. 2001. Screnning of Brazilian plant extracts for antioxidant activity by the use of DPPH free radical method. Phytotherapy Res 15: 127-130.
Morel Fa, Maldaner G, Ilha V, Missau F, Silva FU AND DALCOL I. 2005. Cyclopeptide alkaloids from Scutia buxifolia Reiss and their antimicrobial activity. Phytochemistry 66: 2571-2576.

Muanda FN, Soulimani R, Diop B AND Dicko A. 2011. Study on chemical composition and biological activities of essential oil and extracts from Stevia rebaudiana Bertoni leaves. LWT - Food Sci Techn 44: 1865-1872.

NAZEMIYEH H, LOTFIPOOR F, DElazar A, RAZAVI SM, ASNAASHARI S, Kasebi N, TAlebPour AH, NAHAR L AND SARKER SD. 2011. Chemical composition, and antibacterial and free-radical- scavenging activities of the essential oils of a citronellol producing new chemotype of Thymus pubescens Boiss. \& Kotschy ex Celak. Rec Nat Prod 5: 184-192.

RAYBAUdi-MASSILIA RM, MOSQUEDA-MElgar J AND MARTín-BELloso O. 2006. Antimicrobial activity of essential oils on Salmonella enteritidis, Escherichia coli and Listeria innocua in fruit juices. J Food Protection 69: 1579-1586.

Rivas L, MCDONNEll MJM, BURgess CM, O'Brien M, NAVARRO-VILla A, FANNING S AND DufFy G. 2010. Inhibition of verocytotoxigenic Escherichia coli in model broth and rumen systems by carvacrol and thymol. Int J Food Microbiol 139: 70-78.

Verma RS, PADAlia RC, Chanotiya CS AND CHAUHAN A. 2010. Chemical investigation of the essential oil of Thymus linearis (Benth. ex Benth) from western Himalaya, India. Nat Prod Res 24: 1890-1896.

Viuda-Martos M, Mohamady MA, Fernández-López J, ABD KA, ELRAZIK OAE, PÉREZ-ALVAREZ JA AND SENDRA E. 2011. In vitro antioxidant and antibacterial activities of essentials oils obtained from Egyptian aromatic plants. Food Control 22: 1715-1722.

WASICKY R, WASICKY M AND JOACHIMOVITS R. 1964. Erstuntersuchungen und Coronilha Scutia buxifolia Reissek. Planta Méd 12: 13-25.

Xavier VB, Vargas RMF, Cassel E, Lucas AM, SANTos MA, Mondin CA, SANTAREM ER, ASTARITA LV AND SARTOR T. 2011. Mathematical modeling for extraction of essential oil from Baccharis spp. by steam distillation. Ind Crop Prod 33: 599-604.

YANISHLIEVA NV, MARINOVA EM, GORDON MH AND RANEVA VG. 1999. Antioxidant activity and mechanism of action of thymol and carvacrol in two lipid systems. Food Chem 64: 59-66.

Ziaei A, Ramezani M, Wright L, Paetz C, Schneider B AND AMIRGHOFRAN Z. 2011. Identification of spathulenol in Salvia mirzayanii and the immunomodulatory effects. Phytotherapy Res 25: 557-562. 